Article

\title{
Entrepreneurial Activity in the EU: An Empirical Evaluation of Its Determinants
}

\author{
Valentina Diana Rusu 1,* (iD) and Angela Roman ${ }^{2}$ \\ 1 Department for Interdisciplinary Research in Social Sciences and Humanities, Alexandru Ioan Cuza \\ University of Iasi, 700107 Iasi, Romania \\ 2 Faculty of Economics and Business Administration, Alexandru Ioan Cuza University of Iasi, 700505 Iasi, \\ Romania; aboariu@uaic.ro \\ * Correspondence: valentinadiana.ig@gmail.com; Tel.: +40-74-297-3287
}

Received: 31 July 2017; Accepted: 18 September 2017; Published: 21 September 2017

\begin{abstract}
Entrepreneurship plays a major role in national economies, being considered one of the main engines of economic growth, and an important contributor to creating new jobs and innovations. Identifying the main determinants of entrepreneurial activity is important for helping the decision makers in adopting adequate measures to support the creation and development of new businesses. The turbulent economic environment in recent years dominated by economic and financial crises, resulting in a reduction in economic growth but also in an increase in unemployment, has led decision makers to turn their attention again to the determinant factors of entrepreneurship. Starting from those stated above, through this paper we aim to investigate the impact of some macroeconomic, individual and business environment-related factors on the dynamics of entrepreneurial activity in 18 European Union (EU) countries for a period of 14 years (2002-2015). We use three regression models and we apply panel data fixed effect model approach. The results of our study highlight that inflation rate, foreign direct investments, access to finance and total tax rate are the main macroeconomic determinants of entrepreneurship. Also, we find that all individual business-related factors considered in the analysis have a significant impact on total entrepreneurship rate.
\end{abstract}

Keywords: entrepreneurship; entrepreneurial activity; business; determinants; EU countries; panel data analysis

\section{Introduction}

Entrepreneurship is considered to be a comprehensive, multidimensional concept and is defined by Global Entrepreneurship Monitor (GEM) as "any attempt at new business or new venture creation, such as self-employment, a new business organization, or the expansion of an existing business, by an individual, a team of individuals, or an established business" [1]. According to the Organization for Economic Cooperation and Development (OECD) [2], entrepreneurship is a phenomenon that manifests itself in the whole economy of a country, in different forms, and whose results are not always related to the creation of financial wealth. For example, entrepreneurship can help improve employment, reduce social inequalities, or solve environmental issues.

Entrepreneurship plays a vital role in national economies, being considered one of the main engines of economic growth, and an important contributor to creating new jobs and innovations. The broad recognition of the role of entrepreneurship has led to the shaping of many governmental or regional policies aimed at enhancing entrepreneurship and supporting the survival and growth of new businesses [3-6].

Several studies [7-12] highlight the fact that entrepreneurship plays a major role in the economic development of a country or region and analyze the correlation between entrepreneurial activity and economic growth. 
The G20 Young Entrepreneurs' Alliance (G20 YEA) believes that promoting entrepreneurship in an economy would be supported by five pillars, namely: access to funding (facilitating access to finance for entrepreneurs, in particular through the development by banks of a different lending model for entrepreneurial business, and the development of new innovative financing sources such as crowdfunding and microfinance); entrepreneurship culture (tolerance of risk and failure, preference for self-employment, innovation and research culture); tax and regulation (taxation incentives, ease of starting a business, business-friendly legislation); education and training (entrepreneurship education in pre-university and university education, training for entrepreneurs, encouraging lifelong learning for entrepreneurs), and; coordinated support in all mentioned areas provided by specialized organizations such as associations and clubs of entrepreneurs, governmental agencies, business incubators, clusters, business centers [13] (p. 3). According to the YEA survey, access to funding is an area where entrepreneurs face the most difficulties, so improving access to finance is considered to be the most supportive measure of entrepreneurship development.

The level of entrepreneurial activity differs greatly from one country to another, and within the same country from time to time, and is influenced by several types of factors such as economic, institutional, technological and cultural factors [7,9-11,14-18]. According to Arin et al. [19], the aggregate level of entrepreneurial activity in a country is the result of a multiple interaction between human capital, the level of economic development and institutions.

The economic recession and the significant rise in unemployment in a number of countries, as a result of the recent financial crisis, as well as the significant contribution that entrepreneurship can bring to relaunching national economies and reducing unemployment have led to renewed interest and concerns of researchers as well as decision-makers at different levels for investigation of the factors with potential impact on entrepreneurship.

In this context, our research aims to empirically investigate the impact of some macroeconomic, individual and business environment related factors, identified on the basis of entrepreneurship specialized literature, on the dynamics of entrepreneurial activity in 18 European Union countries over the period 2002-2015.

The added value of our study results from the identification of the key factors that affect the dynamics of entrepreneurial activity in European countries, expressed through the total entrepreneurial activity (TEA), a problem that is less treated in the literature in the field more recently.

To achieve the goal, our study is structured as follows: Section 2 is a synthetic review of literature, particularly of the empirical one, regarding the entrepreneurship determinants; Section 3 presents the data, the analyzed variables and the methodology used; Section 4 highlights and discusses the main results of our empirical study, and the last section includes concluding remarks.

\section{Entrepreneurship Determinants: A Brief Literature Review}

Although the importance of entrepreneurship for the development of national economies is widely recognized, there is no consensus on the factors that stimulate or, on the contrary, hamper entrepreneurial activity.

The analysis of the literature highlights the existence of a large number of theoretical and empirical studies that sought to identify the factors with potential impact on the entrepreneurship dynamics, either in one country or in a group of countries. Thus, Wennekers et al. [20] identify technology, the level of economic development, demography, culture and institutions as determinants of entrepreneurship. Comparatively, Giannetti and Simonov [21] highlight three types of factors which would affect entrepreneurial activity, namely: individual characteristics (e.g., salary, wealth, age, and some demographic characteristic); the economic characteristics of the area where the individual lives (e.g., income per capita, unemployment rate, etc.), and; the characteristics of the social environment (religion, social status of entrepreneurs, education, etc.).

Grilo and Thurik [22] examine, on a sample of countries including 15 European Union (EU) member states, the way that social and demographic factors affect entrepreneurship. The empirical 
study by Wennekers et al. [7] on a group of 36 countries highlights that the dynamics of the nascent entrepreneurship rate is influenced by the degree of economic development of the countries as well as by institutional, demographic and cultural factors. In particular, the authors find that there is a U-shape relationship in between the nascent entrepreneurship rate and the level of economic development. Santarelli and Vivarelli [23] point out that the formation of new firms can be determined by various factors, some of which are progressive factors (e.g., profit expectations, family environment and previous job experience), while others are regressive factors (e.g., low wages, the fear of unemployment). Other studies [24] have examined the impact of gross domestic product (GDP) and GDP per capita (GDPC) growth on entrepreneurial activity and showed that entrepreneurship is significantly related to these macroeconomic factors. In addition, Shane et al. [24] point out that the impact of GDP variation is different depending on the degree of country development. Thus, the authors indicate that in poorer countries, many individuals are turning to entrepreneurship due to lack of employment alternatives. In contrast, in the case of richer countries, individuals consider the option of hiring to be more attractive than starting their own business. Klapper et al. [25] finds out that the entrepreneurship (measured by business entry and density rates) is significantly related to the level of economic development, the quality of the legal and regulatory environment, ease of access to finance and the importance of the informal sector.

Based on regression methods, Kim et al. [26] investigate to what extent the dynamics of entrepreneurial activity in a group of OECD countries, including $17 \mathrm{EU}$ member states, is influenced by public policy. The results of the empirical study indicate that government expenditure on economic affairs and education would make an important contribution to promoting entrepreneurship, and increasing public expenditure to stimulate start-ups would lead to an increase in entrepreneurial activity.

Bosma and Schutjens [14] examine empirically how national and regional conditions have impact on entrepreneurial attitude and activity for 127 regions across 17 European countries during the period 2001-2006. The authors find that certain economic, institutional and demographic factors have a significant impact on the variations of entrepreneurial attitude and activity.

In an empirical investigation of 62 countries on all five continents, Simón-Moya, Revuelto-Taboada and Guerrero [17] analyze how economic and institutional environmental conditions are affecting the level of entrepreneurial activity and the innovation performance of countries. These authors group the sampled countries into three groups according to the characteristics of the economic and institutional environment, and analyze the extent to which the rates of entrepreneurial activity and innovation results vary from one group of countries to another. The survey results show that the three groups of countries are significantly different in terms of both innovation and entrepreneurial activity. Thus, as regards the relationship between the economic environment and the level of entrepreneurship, the authors find that entrepreneurial activity is significantly higher, necessity-driven entrepreneurship plays a more important role and innovation results are weaker in countries with a lower level of development, a higher income inequality and high levels of unemployment. In contrast, in more developed countries, entrepreneurial activity is more reduced, necessity-driven entrepreneurship is less prevalent, and innovation results are improving significantly. With regard to the institutional environment, the results of the survey indicate that the best results in terms of opportunity entrepreneurship and innovation are recorded by the group of countries with higher levels of economic freedom or strong formal institutions.

Other studies $[27,28]$ indicate, based on an empirical investigation, that the most important factors affecting the entrepreneurial activity are: the level of economic development; population growth; employment; the level of education; financial development; macroeconomic stability, and; technological development.

A more recent study [19] analyzes the link between macroeconomic factors and aggregate entrepreneurship. Although 32 macroeconomic indicators are included in the empirical analysis, the results of the study show that only four variables are relevant to explain the links between 
macroeconomic conditions and aggregate entrepreneurship. Therefore, the authors find that GDP per capita, unemployment, marginal tax rate and volatility of inflation are the only macroeconomic variables that are significantly and universally correlated with aggregate entrepreneurship. The results indicate that entrepreneurship is significantly and systematically linked to inflation and taxation, which in turn are directly linked to macroeconomic stability.

Another study of interest [29] analyzes the extent to which the quality of political and economic institutions affects the prevalence of formal and informal entrepreneurship in 18 countries in the Asia-Pacific region over the period 2001-2010. The results of the study indicate that the quality of economic and political institutions is negatively correlated with entry into informal entrepreneurship and is positively associated with entry into formal entrepreneurship. The authors also highlight that the two types of institutions have a complementary effect on entry into formal entrepreneurship, while informal entrepreneurial entries are only influenced individually by economic and political institutions.

Using panel data for 43 countries, Aparicio et al. [11] empirically highlight the institutional factor's impact on opportunity entrepreneurship, and also the impact of this variable on the economic growth. The authors find that informal factors (control of corruption and confidence in skills) have a greater positive impact on opportunity entrepreneurship compared to formal factors (the number of procedures to start a business and private coverage to obtain credit), and opportunity entrepreneurship allows to obtain higher rates of economic growth.

Several authors, such as Black and Strahan; Hurst and Lusardi; Kim et al.; Mueller; Aghion et al.; Musso and Schiavo; Klapper et al.; Werner; Paniagua and Sapena [30-38], analyzed the impact of financial capital and access to finance on entrepreneurship. Overall, the results of the mentioned studies indicate that the availability of financial capital and ease of access to finance can lead to an increase in the number of entrepreneurs, and also to the development of entrepreneurship at the national or regional level.

Our study contributes to expanding knowledge in the field of entrepreneurship by providing some empirical evidence regarding the effect of some macroeconomic, individual and business environment-related factors on the dynamics of entrepreneurial activity in $18 \mathrm{EU}$ member states during the period 2002-2015.

\section{Materials and Methods}

The objective of our analysis is to test which are the possible determinants of entrepreneurship in the European Union member countries, by testing the relationship between a series of indicators and total entrepreneurial activity. The sample contains data for 14 years in sequence, covering the period from 2002 to 2015, and investigates a total of 15 indicators. The annual data for the indicators considered in the analysis are obtained from the Global Entrepreneurship Monitor (GEM) database [39], and World Bank DataBank [40], for 18 European Union member countries (Belgium, Croatia, Denmark, Finland, France, Germany, Greece, Hungary, Ireland, Italy, Latvia, The Netherlands, Portugal, Romania, Slovenia, Spain, Sweden, and United Kingdom). We chose to analyze only 18 European Union member countries due to the availability of data for the entire period considered for each indicator. The data from GEM are harmonized for all the national-level indicators so it is easier to make comparisons between countries regarding entrepreneurial activity.

For measuring the level of entrepreneurial activity, we consider as proxy the total entrepreneurial activity (TEA) rate, which is considered by the Global Entrepreneurship Monitor (GEM) as the most representative indicator to reflect the entrepreneurial phenomenon within an economy. TEA rate is expressed by the percentage of working age population (18-64 years old) who are either a nascent entrepreneur or owner-manager of a new business that is less than 42 months old. This indicator is measured by the GEM through the Adult Population Survey (APS), and it includes nascent entrepreneurs and new entrepreneurs and is of significant importance to a country's economy because from the entrepreneurs involved in this phase of entrepreneurial activity are expected job creation but 
also innovation. At the same time, early-stage entrepreneurs generate dynamism and innovation in an economy.

Talking about factors that are related to entrepreneurship, Hoffmann et al. [41] identify four major categories: performance indicators; business environment indicators; attribute indicators, and; context indicators. The performance indicators are related to the outcome of the entrepreneurial process (e.g., number of start-ups, growth among new firms, job creation), while business environment indicators are considering changeable factors affecting the success of entrepreneur (e.g., access to finance, regulations and administrative burden). Attribute indicators include personal and firm-specific characteristics (e.g., gender, age of entrepreneur), and the context indicators include indicators related to the overall economic environment and institutional context (e.g., GDP, unemployment rate). Starting from this classification and also from the determinants of entrepreneurship identified in the literature review presented above, we concluded that entrepreneurship can be influenced by a series of macroeconomic, institutional, demographic and social indicators. Thus, as explanatory variables for our models, we have chosen a series of indicators by including them into three major categories: indicators measuring macroeconomic stability (combining indicators from business environment and context indicators); indicators related by individual factors (that are measuring the perceived abilities of individuals and their attitudes towards entrepreneurship. Hoffmann et al. [41] argue that these indicators belong to both the business environment indicators-because they affect the willingness of a person to start a new business- and the attribute indicators-because they are characteristics of individuals), and; indicators expressing the opportunities of starting a firm (which are presented by Hoffmann et al. [41] as a subcategory of the business environment indicators). For each category we have considered the most representative indicators as determinants of entrepreneurship (according to the ones identified in the specialized literature), thus we can say that we also solved the problem of omitted variables.

From the first group of indicators we have considered seven variables: GDP; GDP per capita; tax rate; inflation rate; foreign direct investments; access to credit, and; unemployment rate. The gross domestic product (GDP-expressed as annual percentage growth rate) and gross domestic product per capita (GDP per capita-expressed as annual percentage growth rate) are important macroeconomic factors which can have impact on the entrepreneurial activity. According to some studies [11,22,36,42], the increase of GDP per capita has a positive impact on entrepreneurship because the increase of incomes can determine an increased demand for a wide range of goods and services that would stimulate entrepreneurial activity, especially new business start-ups. As a result of our analysis, we expected a positive relationship between GDP per capita growth and entrepreneurship. Other studies $[19,24]$ show that the impact of GDP per capita on entrepreneurship depends on the degree of economic development of the country. Thus, in poorer countries, the relationship between GDP per capita and entrepreneurship is negative because low GDP levels cause individuals to start their own business due to lack of employment alternatives. In contrast, for richer countries, labor markets offer more stable jobs, and individuals think the employment option is more attractive than starting their own business.

Entrepreneurial activity can also be affected by total tax rate (tax) (as \% of commercial profits). The tax policy of a country has a major influence on the decision of a person to become entrepreneur, because it can make this activity more or less attractive compared with the wages offered for their work. In accordance with the studies analyzing this indicator $[19,25,42-46]$, high tax rates lead to lower self-employment, because they are seen as an obstacle for starting new business and lead to a decrease in business activity. Thus, we expect a negative relationship between tax rates and entrepreneurial activity.

Another important macroeconomic factor considered as a determinant of entrepreneurial activity is the inflation rate (INFL) (consumer prices, annual \%), which also does not have a clear relationship with entrepreneurship. Thus, according to some studies $[28,42,47,48]$ if inflation increases, it can be recorded an increase in business opportunities because higher price levels for products and services 
can lead to increased expectations of the earnings of entrepreneurs. On the other hand, inflation can discourage entrepreneurship because the business environment is considered riskier, it increases costs for starting a business $[19,46]$, and increases the population's income inequality and reduces the reward entrepreneurship, becoming an obstacle to entrepreneurship [49]. Also, high rates of inflation reduce the access to financial resources of firms due to higher borrowing costs and, thus, reduce the likelihood of entrepreneurship [50]. Therefore, the relationship between inflation and entrepreneurship can be either negative or positive.

With regard to foreign direct investments (net inflows as \% of GDP) (FDI), the theoretical and empirical studies highlight that FDI can have both positive and negative effects on entrepreneurial activity. Meyer and Sinani [51] showed that the effects of FDI on entrepreneurship vary across countries at different levels of economic development. Some studies [52-54] have found that FDI positively affect entrepreneurship, highlighting that the power of this effect depends on the level of development of the country, but also on the institutional support offered to entrepreneurship, political stability and the good quality of human capital. The positive impact of foreign direct investments results from the fact that they determine an increase of trade flows, sustain export competitiveness, and can stimulate the import-competing production, but also can provide managerial skills for entrepreneurs by the mobility of managers and workers into the foreign-owned firms. On the other hand, other research [55-59] has found a negative effect or no effect of FDI on the entry of new domestic firms, especially in developing economies. Negative effects can appear when foreign-owned firms compete for the same customers and affect domestic firms [57]. The presence of foreign firms in an industry can have a negative impact on the entry of domestic firms by raising the technological barriers to entry [59]. The contradictory results obtained in the specialized literature can be associated with the lack of distinction between opportunity and necessity-driven entrepreneurs. The necessity driven entrepreneurs are the persons that are involved in entrepreneurial activities because they do not have other options for work and seek to secure an income necessary for living. By comparison, the opportunity driven entrepreneurs are those people who want to start a business from the desire to be independent in their work or to increase their income [39]. Van der Zwan et al. [60] find that opportunity business owners are more likely to be male, younger, and wealthier (in terms of household income), and to have a higher preference for business ownership compared to paid employment than necessity business owners. Also, the authors found that opportunity and necessity business owners have similar education levels and do not significantly differ in terms of the self-employment background of their parents. Starting from those stated above, we observe that the relationship between foreign direct investments inflows and total entrepreneurship rate can be either negative or positive.

A series of studies and surveys indicate that one of the most important problems for entrepreneurship, especially for small and younger firms, is the ease of access to finance (ACCESS). For this reason, we intend to investigate empirically the relation between this variable and entrepreneurial activity. In the case of companies from the European countries, the most important source of external financing is represented by bank loans, so we considered domestic credit to the private sector by banks as share in GDP. This indicator is a proxy for access to finance and can be positively correlated with entrepreneurship as the increase in credit flows to the private sector reflects a more easy access to finance that would stimulate new business start-ups and increase existing businesses [19,28,34,36,42]. Therefore, we expect a positive sign of the relationship. On the other hand, some studies [31-33] have indicated a negative relationship between access to finance and entrepreneurship explaining the result by the fact that access to finance is not a problem for most early stages business because much of them do not need large amounts of financial capital; thus, new start-ups will continue to enter on the market, contributing to the increase of total entrepreneurship rate, even if their access to bank loans will decrease (e.g., in case of economic downturn or a financial crisis).

Unemployment rate (UNEMPL) (\% of total labor force) is another macroeconomic variable that can affect entrepreneurial activity. Because founding a new firm may be an alternative to future uncertain career prospects, Vivarelli [61] showed that job loses is an important factor that determines new firm 
formation at regional level, and entrepreneurship is seen as an escape from unemployment. Santarelli and Vivarelli [23] have shown that unemployment plays a particularly significant role, for certain countries, during economic downturn. Thus, according to various empirical studies [14,19,22,28,42,61], the relationship between unemployment rate and entrepreneurship is uncertain. On the one hand, a significant increase in the rate of unemployment may lead to a decrease in demand for goods and services that reduce business opportunities. On the other hand, rising unemployment may cause more people to opt for having their own business, for reasons of necessity.

Entrepreneurship is determined also by individual factors (or by the personal characteristics of the entrepreneurs who are represented in our study by the abilities of individuals and their attitudes towards entrepreneurship). Olivari [62] highlighted the role of the motivation and attitudes of entrepreneurs for the success of the business. He showed that intrinsically motivated and highly educated entrepreneurs are more likely to have an innovative business. From this category of indicators we have chosen as determinants of entrepreneurship the perceptions of individuals. Thus, the variable perceived capabilities (CAPAB), measures the percent of persons who consider that they have the required skills, knowledge and experience to start their own business. If a large number of people are confident in their abilities to run a business then they will be encouraged in setting up new businesses. So, for this variable, we expect a positive sign. The same sign we expect for the variable perceived opportunities (OPPORT), which represents the percentage of people that see good opportunities to start a firm in the area where they live. The fear of failure rate (FOF) expresses the percent of persons with positive perceived opportunities which indicate that the fear of failure would prevent them to create a new business. This variable is negatively correlated with the level of entrepreneurial activity (in accordance with the findings by Albulescu and Tamasila [27]) because fear of failure is considered a constraining factor for creating and starting a new business. The entrepreneurial intentions (EINT) variable expresses, according Singer et al. [63], the percentage of individuals who expect to start a business within the next three years. This variable is positively correlated with the entrepreneurial activity, so we expect a positive sign.

The demand for entrepreneurship arises from the opportunities of starting a firm, including business environment characteristics, so for our study we want to test if cost of business start-up procedures (COST) [14], time required to start a business (TIME) and number of procedures needed for establishing a new firm (NOPROC) have a significant impact on entrepreneurship. Some studies $[7,9,22,25,34,64]$ show that entry of the firms on the market is hampered by bureaucratic barriers such as costs, procedures and time required to start a business, and also by employment rigidity. For these variables, we expect a negative relationship with total entrepreneurial activity.

The relationships mentioned above are described from the point of view of our research, but we have to mention that for some variables the inverse relationship exists also. For example, some studies $[65,66]$ have tested if the total entrepreneurial activity influences the GDP growth and have showed that entrepreneurial activity affects economic growth, but the effect depends upon the level of GDP per capita, the types of start-ups and the regional environment. Thus, entrepreneurship plays a different role in countries according to their stage of economic development. Additionally, the formation of new enterprises may have effects on unemployment rate, but the effect depends on the country or region where they activate [67-69].

In order to statistically analyze the data, we applied unit-root tests on every variable included in the panel data to test if data is stationary and control for false relationships among variables. The null hypothesis is that all variables contain unit-root. This hypothesis was rejected in almost all the cases. For the variables that had a unit-root we determined the first difference (for unemployment, entrepreneurial intentions and time needed to start a new business) thus ensuring the basic conditions to perform a regression analysis on this data.

The following steps taken were: the analysis of the descriptive statistics of variables included in the research, the correlations between variables and regression analysis using three different models for each category of explanatory variables used. To obtain the estimated coefficients of the regression 
models, we have applied the panel data fixed effect model. This panel data model is usually used for testing the entrepreneurship determinants because fixed effects help eliminate the disparities between countries.

The general tested equations for fixed effect models are:

$$
Y_{i t}=\beta_{0}+\beta_{1} X_{i t}+\alpha_{i}+\varepsilon_{i t}
$$

where $Y_{i t}$ is the dependent variable (TEA); $\beta_{0}$ is the intercept; $X_{i t}$ represents the vector of independent variables; $\beta_{1}$ are the coefficients; $\alpha_{i}$ represents all the stable characteristics of the countries; $i=\mathrm{BE}, \ldots$, UK represents the unknown intercept of every country; $t=2002, \ldots, 2015$ is the year analyzed; $\varepsilon_{i t}$ is the error term.

The equations adapted for the three models of regression are:

$$
\begin{gathered}
\text { Model 1: TEA } A_{i t}=\alpha_{i}+\beta_{1} g d p_{i t}+\beta_{2} g d p c_{i t}+\beta_{3} \text { tax }_{i t}+\beta_{4} \text { unempl }_{i t}+\beta_{5} \text { infl }_{i t}+\beta_{6} f d i_{i t}+\beta_{7} d c p s_{i t}+\varepsilon_{i t} \\
\text { Model 2: TEA } A_{i t}=\alpha_{i}+\beta_{1} f_{0} f_{i t}+\beta_{2} \text { eint }_{i t}+\beta_{3} \text { capab }_{i t}+\beta_{4} \text { opport }_{i t}+\varepsilon_{i t} \\
\text { Model 3: } T E A_{i t}=\alpha_{i}+\beta_{1} \text { cost }_{i t}+\beta_{2} \text { time }_{i t}+\varepsilon_{i t}
\end{gathered}
$$

The results of the empirical analysis are presented in the following section.

\section{Results and Discussions}

We started the empirical analysis by presenting the descriptive statistics of the variables considered for our study. Table 1 summarizes the descriptive statistics of the dependent and explanatory variables. The total entrepreneurial activity (TEA) rate varies across economies and over time, from almost $2 \%$ of working-age population to $14 \%$, this variation being due to differences in macroeconomic conditions, the ease of formal business registration and other regulatory factors that affect the entrepreneurial environment. For better empirical results, we have included the determinants of entrepreneurship in three groups: indicators measuring macroeconomic stability; indicators related of individual factors, and; business environment-related indicators (the opportunities of starting a firm).

Table 1. Descriptive statistics of TEA rate and independent variables.

\begin{tabular}{ccccccc}
\hline Variable & Min. & Max. & Mean & $\begin{array}{c}\text { Std. } \\
\text { Deviation }\end{array}$ & Skewness & Kurtosis \\
\hline TEA & 1.88 & 14.11 & 6.237 & 2.186 & 0.939 & 4.086 \\
GDP & -14.35 & 11.90 & 0.920 & 3.640 & -0.605 & 5.084 \\
GDPC & -12.92 & 12.93 & 0.703 & 3.670 & -0.212 & 5.045 \\
TAX & 18.40 & 76.70 & 44.535 & 13.626 & 0.171 & 2.363 \\
INFL & -4.48 & 15.40 & 2.385 & 2.110 & 1.733 & 11.737 \\
FDI & -16.07 & 87.44 & 6.619 & 11.743 & 3.320 & 18.055 \\
ACCESS & 0.22 & 202.19 & 100.932 & 44.461 & 0.381 & 2.563 \\
UNEMPL & 2.80 & 27.20 & 9.331 & 4.628 & 1.862 & 6.829 \\
FOF & 15.12 & 61.58 & 37.058 & 7.343 & 0.419 & 4.104 \\
EINT & 1.55 & 31.70 & 9.564 & 5.101 & 1.561 & 5.800 \\
CAPAB & 14.58 & 60.67 & 42.450 & 7.775 & -0.245 & 3.279 \\
OPPORT & 2.85 & 71.49 & 31.964 & 14.020 & 0.714 & 3.161 \\
COST & 0.00 & 22.50 & 5.820 & 6.382 & 1.216 & 3.353 \\
TIME & 2.50 & 70.00 & 14.543 & 13.002 & 2.447 & 9.083 \\
NOPROC & 3.00 & 15.00 & 6.139 & 2.818 & 1.235 & 4.407 \\
\hline
\end{tabular}

Source: authors' calculations using the data provided by Global Entrepreneurship Monitor (GEM) database and World Bank Data Bank. Total entrepreneurial activity (TEA); gross domestic product (GDP); GDP per capita (GDPC); total tax rate (TAX); inflation rate (INFL); foreign direct investments (FDI); ease of access to finance (ACCESS); unemployment rate (UNEMPL); fear of failure rate (FOF); entrepreneurial intentions (EINT); perceived capabilities (CAPAB); perceived opportunities (OPPORT); cost of business start-up procedures (COST); time required to start a business (TIME); number of procedures needed for establishing a new firm (NOPROC). 
Thus, from the category of macroeconomic stability indicators we find that the domestic credits granted by banks to the private sector have registered the highest variation. The smallest value of the credits granted to private sector was registered in Slovenia for a period of five years, 2004-2008 (under $1 \%$ of GDP), while the highest value of this indicator was registered in Denmark (in 2009, 202\% of GDP). The high value of standard deviation highlights that there exist important differences between countries regarding their degree of financial development.

Another indicator which has registered important disparities among countries was the tax rate (it varied between $76 \%$ of commercial profits in Italy in 2005, to $18 \%$ in Croatia in 2014). Tax regimes represent one of the most important obstacles to entrepreneurship, so the very high values of tax rates recorded in some countries considered in the study are perceived as true impediments and inhibit the development of entrepreneurial activities.

Foreign direct investments net inflows (as \% of GDP) also had high values of standard deviation. The highest value of FDI inflows was registered in Netherlands in 2007 (87\%), and the smallest value was registered in Hungary in $2010(-16 \%)$. The inflows of capital sustain the economic development of countries which can lead to better entrepreneurship opportunities. The negative minimum value of foreign direct investments inflows show that for those countries outflows of investment exceeded the value of inflows.

The negative minimum values for GDP and GDP per capita expressed as annual percentage growth show that the analyzed EU countries in the period of 14 years considered in the study had periods of reduction of their economic development.

As far as the inflation rate is concerned, it recorded a minimum value of $-4.48 \%$ (Ireland, 2009) and a maximum of $15.43 \%$ (Latvia, 2008).

Among the indicators measuring the perceived abilities of individuals and their attitudes towards entrepreneurship, the indicator measuring perceived opportunities varied the most, from almost $3 \%$ of working age population seeing good opportunities to start a business in the area they live in Hungary (2009), to 71\% of working age population in Sweden (2011). Perceived capabilities have also registered important variations, from $14 \%$ of working age population who considered that have the skills and knowledge to start a business in Hungary (2005), to $61 \%$ of working age population in Croatia (2007).

From the third category of factors, the time needed to start a new business, registered a high standard deviation expressing important variations from 2.5 days needed to start a new business in Portugal (2013 and 2014) to 70 days in Spain (2005). Cost of business start-up procedures varied from no costs in Denmark for almost all the period considered for the analysis to $22 \%$ of Gross National Income (GNI) per capita in Hungary (2005).

The correlation matrix of the considered variables is presented in Table 2. For some of the explanatory variables a high correlation coefficient (above 0.70 ) is observed. The specialized literature does not consider a unitary value for expressing a high correlation. For example, Kennedy [70] states that correlation is high when its value is above 0.80 or 0.90 . However, other authors $[71,72]$ consider that there exists multicollinearity when the correlation coefficient is higher than 0.70 or 0.80 . We consider as reference point the value of 0.70 . Because we identify the presence of multicollinearity between some of the explanatory variables, we use separate regression models by excluding one of the two highly correlated variables, and so obtain accurate results.

Through the regression analysis we aimed at identifying which are the factors that determine the entrepreneurial activity in the EU countries. We also test which model explains better the dynamics of total entrepreneurial activity rate in the considered countries. In order to empirically analyze the relationship between entrepreneurial activity and the considered factors, we use three regression models (each one corresponding to a certain category of factors), and we apply panel data fixed effect model approach. We also determine the estimator variance-covariance matrix by the White cross method. In Table 3 are summarized the results of the applied regression models. 
Table 2. Correlation matrix.

\begin{tabular}{|c|c|c|c|c|c|c|c|c|c|c|c|c|c|c|c|}
\hline & TEA & GDP & GDPC & TAX & INFL & FDI & ACCESS & UNEMPL & FOF & EINT & САРАВ & OPPORT & COST & TIME & NOPROC \\
\hline (1) TEA & 1.000 & & & & & & & & & & & & & & \\
\hline (2) GDP & -0.209 & 1.000 & & & & & & & & & & & & & \\
\hline (3) GDPC & -0.171 & $0.998 *$ & 1.000 & & & & & & & & & & & & \\
\hline (4) TAX & $-0.775^{*}$ & 0.513 & 0.470 & 1.000 & & & & & & & & & & & \\
\hline (5) INFL & -0.428 & 0.390 & 0.380 & 0.368 & 1.000 & & & & & & & & & & \\
\hline (6) FDI & -0.372 & 0.612 & 0.588 & 0.573 & $0.682 *$ & 1.000 & & & & & & & & & \\
\hline (7) ACCESS & -0.037 & $-0.679 *$ & -0.674 * & -0.530 & 0.038 & -0.283 & 1.000 & & & & & & & & \\
\hline (8) UNEMPL & $0.743 *$ & -0.412 & -0.369 & -0.843 & -0.661 * & -0.797 * & 0.179 & 1.000 & & & & & & & \\
\hline (9) FOF & -0.947 * & -0.304 & -0.269 & -0.696 * & -0.447 & -0.502 & -0.087 & $0.755 *$ & 1.000 & & & & & & \\
\hline (10) EINT & $0.908 *$ & -0.130 & -0.081 & $-0.840 *$ & -0.431 & -0.456 & -0.006 & $0.877^{*}$ & $0.829 *$ & 1.000 & & & & & \\
\hline (11) CАРAB & -0.527 & -0.049 & -0.057 & 0.024 & -0.035 & -0.090 & 0.552 & -0.135 & $-0.645^{*}$ & -0.342 & 1.000 & & & & \\
\hline (12) OPPORT & -0.183 & $0.944 *$ & $0.942 *$ & 0.460 & 0.394 & $0.711 *$ & -0.593 & -0.449 & -0.317 & -0.117 & -0.017 & 1.000 & & & \\
\hline (13) COST & $-0.838 *$ & 0.477 & 0.443 & $0.936 *$ & 0.487 & 0.512 & -0.463 & $-0.777^{*}$ & -0.749 * & -0.791 * & 0.067 & 0.415 & 1.000 & & \\
\hline (14) TIME & $-0.753 *$ & 0.503 & 0.468 & $0.949 *$ & 0.419 & 0.501 & -0.575 & -0.757 * & $-0.664 *$ & -0.746 * & -0.032 & 0.423 & $0.984 *$ & 1.000 & \\
\hline (15) NOPROC & $-0.852 *$ & 0.433 & 0.399 & $0.884 *$ & 0.549 & 0.563 & -0.357 & $-0.795^{*}$ & $-0.796^{*}$ & -0.789 * & 0.134 & 0.398 & $0.979 *$ & $0.951 *$ & 1.000 \\
\hline
\end{tabular}


Table 3. Determinants of entrepreneurial activity in EU-18 countries.

\begin{tabular}{|c|c|c|c|c|c|c|c|}
\hline & TEA & Coef. & Prob. & Constant & F-Test & R-Squared & $\begin{array}{l}\text { Adjusted } \\
\text { R-Squared }\end{array}$ \\
\hline \multirow{7}{*}{ Model 1} & GDP & -0.013 & 0.733 & \multirow{7}{*}{$11.378^{* * *}$} & \multirow{7}{*}{$9.627^{* * *}$} & \multirow{7}{*}{0.5504} & \multirow{7}{*}{0.4932} \\
\hline & GDPC & -0.030 & 0.520 & & & & \\
\hline & TAX & $-0.062 *$ & 0.085 & & & & \\
\hline & INFL & $-0.232 * * *$ & 0.000 & & & & \\
\hline & FDI & $-0.019^{* *}$ & 0.058 & & & & \\
\hline & ACCESS & $-0.016^{* *}$ & 0.012 & & & & \\
\hline & UNEMPL & -0.036 & 0.466 & & & & \\
\hline \multirow{4}{*}{ Model 2} & FOF & $0.082 * * *$ & 0.000 & \multirow{4}{*}{$-3.588^{* * *}$} & \multirow{4}{*}{$\underset{* * *}{15.012}$} & \multirow{4}{*}{0.5793} & \multirow{4}{*}{0.5407} \\
\hline & EINT & $0.140^{* * *}$ & 0.000 & & & & \\
\hline & CAPAB & $0.140^{* * *}$ & 0.000 & & & & \\
\hline & OPPORT & $0.023^{* * *}$ & 0.008 & & & & \\
\hline \multirow{3}{*}{ Model 3} & COST & $-0.101^{* * *}$ & 0.000 & \multirow{3}{*}{$6.760 * * *$} & \multirow{3}{*}{$9.941^{* * *}$} & \multirow{3}{*}{0.4588} & \multirow{3}{*}{0.4127} \\
\hline & TIME & $-0.024^{* * *}$ & 0.000 & & & & \\
\hline & NOPROC & $-0.247^{* * *}$ & 0.000 & & & & \\
\hline
\end{tabular}

Note: ${ }^{* * *}$ and ${ }^{* * *}$ denotes that coefficients are significantly at the $10 \%, 5 \%$ and $1 \%$ level. Source: authors' calculations using the data provided by GEM database and World Bank Data Bank.

For Model 1, because we found that are variables highly correlated: GDP and GDP per capita, but also unemployment rate with tax rate and FDI, we applied four different panel data regression models $\left(T E A_{i t}=\alpha_{i}+\beta_{1} g d p_{i t}+\beta_{2} \operatorname{tax}_{i t}+\beta_{3} i n f l_{i t}+\beta_{4} f d i_{i t}+\beta_{5} d c p s_{i t}+\varepsilon_{i t} ; T E A_{i t}=\alpha_{i}+\beta_{1} g d p c_{i t}+\beta_{2} \operatorname{tax}_{i t}+\beta_{3} i n f l_{i t}+\right.$ $\beta_{4} f d i_{i t}+\beta_{5} d c p s_{i t}+\varepsilon_{i t} ; T E A_{i t}=\alpha_{i}+\beta_{1} g d p_{i t}+\beta_{2}$ unempl $_{i t}+\beta_{3}$ inflit $+\beta_{4} d c p s_{i t}+\varepsilon_{i t} ; T E A_{i t}=\alpha_{i}+\beta_{1} g d p c_{i t}+$ $\beta_{2} u_{n e m p l}+\beta_{3}$ infl $\left._{i t}+\beta_{4} d c p s_{i t}+\varepsilon_{i t}\right)$. The results obtained for the coefficient, probability and R-squared were quite similar for all the models, so we centralized the results in the first part of Table 3.

Thus, based on the results of the fixed effects regression models and the statistically significant coefficients obtained for Model 1, we can conclude that inflation rate, foreign direct investments, access to finance and total tax rate are between the main macroeconomic indicators that are significantly correlated with total entrepreneurial activity. For Model 2, the empirical results indicate that entrepreneurial activity is strongly affected by all the considered indicators measuring the perceived abilities of individuals and their attitudes towards entrepreneurship. The results obtained for Model 3 show that all the considered indicators measuring the opportunities for starting a new business have a statistically significant influence on entrepreneurial activity. In the case of this model, we found that all the variables were highly correlated, thus we ran single regression models corresponding to each variable. The value of R-square was similar for each single regression model (0.4588).

Generally speaking, our results are consistent with the predictions of theoretical studies, but also with the results of other empirical studies. The coefficient for the total tax rate is negative and statistically significant, such that the entrepreneurial activity is discouraged when the tax rate increases. Therefore, the tax rate is an important obstacle to entrepreneurial activity. Tax rates also have a major influence on the decision of a person to become entrepreneur because it can make this activity more or less attractive compared with the wages offered for their work. The level of tax rate can attract potential entrepreneurs so that they become self-employed, or it can push workers out of wage jobs and into self-employment. This result is in agreement with our expectations and also with the findings of some studies [25,28,42-46].

The coefficient of inflation rate is negative and statistically significant at $1 \%$. These results are in accordance with our expectations but also with the findings of some empirical studies. Some studies $[19,45,49,50]$ have also found a negative effect of inflation on entrepreneurship because it increases costs for starting a business, reduce the access to capital of firms and increases the population's income inequality. 
Foreign direct investments inwards have also a negative coefficient and statistically significant at a $5 \%$ level. The negative coefficient is in agreement with the results obtained by the empirical studies mentioned. Some authors $[15,18,55-58]$ find a negative effect or no effect of the FDI on the entry of new domestic firms, especially in developing economies. This can be explained by the fact that when new investors enter into the country (increased inward FDI), the opportunity-driven entrepreneurial activity increases, while necessity-driven activity decreases, many persons find good paid jobs and do not try to look for alternative revenues, respectively revenues from entrepreneurial activity. In the countries where the total entrepreneurial activity is dominated by necessity-driven entrepreneurs, the effect of FDI on entrepreneurial activity is negative.

The results of our empirical analysis on access to finance indicate a negative relationship, contrary to our expectations, but in agreement with the results obtained by Sayed and Slimane [28], Klapper et al. [36]. The coefficient is statistically significant at a 5\% level. A possible explanation for this result is that the reduction in credit flows to the private sector, especially in the context of the recent international crisis, did not discourage the likelihood of being an entrepreneur, because creating new businesses and running them in the early stages does not require such significant financial resources.

The other macroeconomic indicators considered in the study, respectively GDP, GDP/capita and unemployment rate, do not have a statistically significant relationship with entrepreneurial activity of EU-18 countries.

When analyzing the results obtained for Model 2, we observe that all four explanatory variables considered have a significant relationship with entrepreneurship in the European Union member countries. Thus, entrepreneurial intentions, perceived capabilities and perceived opportunities are positively related with entrepreneurial activity. If entrepreneurial intentions are rising then entrepreneurial activity on the market will improve. Also, if there is registered an increase of the perceptions regarding the capabilities of individuals to be entrepreneurs and also of the opportunities on the market for entrepreneurs, entrepreneurial activity is stimulated. These results are in line with our expectations. In accordance with the findings of Albulescu and Tămăşilă [27] and with our expectations, the fear of failure has a negative influence on the option of entrepreneurs to start-up a new business.

Model 3 highlights that all three variables considered in the analysis have a negative statistically significant relationship with total entrepreneurship rate. These results are in line with our expectations and also with the findings of some studies $[11,25,34,36,38,64]$. If the cost of establishing a new business is high, and also if the time needed to start-up a new firm is long or many procedures are needed, potential entrepreneurs will be discouraged.

The effects of the investigated variables, combined for each model, had a medium impact on total entrepreneurship rate as shown by R-squared value (and R-squared adjusted) of around $50 \%$. These results highlight the fact that there are also other factors that may have an important influence on entrepreneurial activity. Comparing the value of the R-squared adjusted for the three models, we observe that the perceived abilities of individuals and their attitudes towards entrepreneurship have the biggest influence on total entrepreneurial activity $(54 \%)$. The indicators measuring macroeconomic stability explain almost $50 \%$ of the variation of total entrepreneurship rate, and the indicators expressing the opportunities of starting a firm express $41 \%$ of the variation in total entrepreneurship rate.

\section{Conclusions}

In this paper, we have tested the relationship between a number of 14 factors identified in the entrepreneurship specialized literature and the dynamics of total entrepreneurial activity in $18 \mathrm{EU}$ member countries. The main objective of our study was to test the hypotheses and to offer empirical evidence with respect to the key factors that affect the dynamics of total entrepreneurial activity in European countries. For the accuracy of the results, we have grouped the explanatory variables in three 
categories, namely: indicators measuring macroeconomic stability; indicators related of individual factors, and; business environment-related factors.

The empirical results obtained show that inflation rate, foreign direct investments, access to credit and total tax rate are between the main macroeconomic indicators that are significantly correlated with total entrepreneurial activity. Our findings are in accordance with the results obtained by other empirical studies. For the second category of factors, we saw that fear of failure, entrepreneurial intentions, perceived capabilities and perceived opportunities have a significant relationship with total entrepreneurship rate. Regarding the third group of indicators, describing the opportunities in starting up a new business, all the variables investigated (cost of business start-up procedures, time required to start a business and number of procedures needed for establishing a new firm) were found to have a statistically significant relationship with entrepreneurial activity.

Thus, we can conclude that the economic development of a country, the abilities of individuals, their attitudes towards entrepreneurship and the opportunities in starting a business offered by a country are the key factors that affect the dynamics of entrepreneurial activity from the 18 European Union countries analyzed. Only $50 \%$ from the variation of the total entrepreneurship rate is explained by the variation of the considered variables, thus there are also other factors that could determine entrepreneurial activity. This limitation of our study illustrates to us that other factors besides those analyzed here should be analyzed in future research. Moreover, the effects of some of the considered variables could have another impact if we analyze entrepreneurship according to the reason why the person becomes an entrepreneur (by necessity or opportunity).

Our study can be further developed in different directions. First, depending on the availability of data, we can test if there are differences between the indicators that affect entrepreneurial activity in two groups of countries, developed and developing ones. Second, we can make the distinction between opportunity-driven entrepreneurs and necessity-driven ones, which could led to different results.

Author Contributions: Both authors conceived the study and contributed equally to the writing of the paper.

Conflicts of Interest: The authors declare no conflict of interest.

\section{References}

1. Reynolds, P.D.; Hay, M.; Camp, S.M. Global Entrepreneurship Monitor, Executive Report; Kauffman Center for Entrepreneurial Leadership: Kansas City, MO, USA, 1999.

2. OECD. Entrepreneurship at a Glance 2012; OECD: Paris, France, 2012.

3. European Commission. Entrepreneurship 2020 Action Plan, Reigniting the Entrepreneurial Spirit in Europe; COM (2012) 795 Final; European Commission: Brussels, Belgium, 2013.

4. Pergelova, A.; Angulo-Ruiz, F. The impact of government financial support on the performance of new firms: The role of competitive advantage as an intermediate outcome. Entrep. Reg. Dev. 2014, 26, 663-705. [CrossRef]

5. Acs, Z.; Astebro, T.; Audretsch, D.; Robinson, D.T. Public policy to promote entrepreneurship: A call to arms. Small Bus. Econ. 2016, 47, 35-51. [CrossRef]

6. Nuta, A.C.; Ariton, D.; Nuta, F.M. Social and economic cohesion in Romania for sustainable development in the context of anti crisis policies. Rev. Econ. 2011, 2, 488-494.

7. Wennekers, S.; van Stel, A.; Thurik, R.; Reynolds, P. Nascent Entrepreneurship and the Level of Economic Development. Small Bus. Econ. 2005, 24, 293-309. [CrossRef]

8. Wong, P.K.; Ho, Y.P.; Autio, E. Entrepreneurship, innovation and economic growth: Evidence from GEM data. Small Bus. Econ. 2005, 24, 335-350. [CrossRef]

9. Van Stel, A.; Storey, D.J.; Thurik, A.R. The effect of business regulations on nascent and young business entrepreneurship. Small Bus. Econ. 2007, 28, 171-186. [CrossRef]

10. Acs, Z.J.; Desai, S.; Hessels, J. Entrepreneurship, economic development and institutions. Small Bus. Econ. 2008, 31, 219-234. [CrossRef]

11. Aparicio, S.; Urbano, D.; Audretsch, D. Institutional factors, opportunity entrepreneurship and economic growth: Panel data evidence. Technol. Forecast. Soc. 2016, 102, 45-61. [CrossRef] 
12. Nițu-Antonie, R.D.; Feder, E.S.; Munteanu, V.P. Macroeconomic Effects of Entrepreneurship from an International Perspective. Sustainability 2017, 9, 1159. [CrossRef]

13. McMorrow, C.; St-Jean, C.A. The Power of Three: Together, Governments, Entrepreneurs and Corporations Can Spur Growth Across the G20. EY G20 Entrepreneurship Barometer. 2013. Available online: http:/ / www.ey.com/Publication/vwLUAssets/EY-G20-Entrepreneurship-Barometer2013-Canada/\$FILE/EY-G20-Entrepreneurship-Barometer-2013-Canada.pdf (accessed on 15 March 2017).

14. Bosma, N.; Schutjens, V. Understanding regional variation in entrepreneurial activity and entrepreneurial attitude in Europe. Ann. Reg. Sci. 2011, 47, 711-742. [CrossRef]

15. Danakol, S.H.; Estrin, S.; Reynolds, P.; Weitzel, U. Foreign Direct Investment and Domestic Entrepreneurship: Blessing or Curse? Available online: http://eprints.lse.ac.uk/60281/1/dp1268.pdf (accessed on 10 March 2017).

16. Herrera-Echeverri, H.; Haar, J.; Estéve-Bretón, J.B. Foreign direct investment, institutional quality, economic freedom and entrepreneurship in emerging markets. J. Bus. Res. 2014, 67, 1921-1932. [CrossRef]

17. Simón-Moya, V.; Revuelto-Taboada, L.; Guerrero, R.F. Institutional and economic drivers of entrepreneurship: An international perspective. J. Bus. Res. 2014, 67, 715-721. [CrossRef]

18. Chowdhury, F.; Terjesen, S.; Audretsch, D. Varieties of entrepreneurship: Institutional drivers across entrepreneurial activity and country. Eur. J. Law Econ. 2015, 40, 121-148. [CrossRef]

19. Arin, K.P.; Huang, V.Z.; Minniti, M.; Nandialath, A.M.; Reich, O.F. Revisiting the determinants of entrepreneurship: A Bayesian approach. J. Manag. 2015, 41, 607-631. [CrossRef]

20. Wennekers, S.; Uhlaner, L.M.; Thurik, R. Entrepreneurship and its conditions: A macro perspective. Int. J. Entrep. Educ. 2002, 1, 25-64.

21. Giannetti, M.; Simonov, A. On the Determinants of Entrepreneurial Activity: Social Norms, Economic Environment and Individual Characteristics. Swed. Econ. Policy Rev. 2004, 11, 269-313. [CrossRef]

22. Grilo, I.; Thurik, R. Determinants of Entrepreneurship in Europe. Available online: http://papers.econ.mpg. de/egp/discussionpapers/2004-30.pdf (accessed on 10 April 2017).

23. Santarelli, E.; Vivarelli, M. Entrepreneurship and the process of firms' entry, survival and growth. Ind. Corp. Chang. 2007, 16, 455-488. [CrossRef]

24. Shane, S.A. The Illusion of Entrepreneurship: The Costly Myths that Entrepreneurs, Investors and Policy Makers Live by; Yale University: New Haven, CT, USA, 2008; ISBN 978-0-300-11331-0.

25. Klapper, L.; Laeven, L.; Rajan, R. Entry regulation as a barrier to entrepreneurship. J. Financ. Econ. 2006, 82, 591-629. [CrossRef]

26. Kim, Y.; Kim, W.; Yang, T. The Effect of Public Policy on Entrepreneurial Activity: Evidence from OECD Countries. In Proceedings of the ICSB World Conference, Cincinnati, OH, USA, 24-27 June 2010.

27. Albulescu, C.T.; Tămăşilă, M. The impact of FDI on entrepreneurship in the European Countries. Procedia Soc. Behav. Sci. 2014, 124, 219-228. [CrossRef]

28. Sayed, O.; Slimane, S.B. An Appraisal of the Determinants of Entrepreneurship in Developing Countries: The Case of the Middle East, North Africa and Selected Gulf Cooperation Council Nations. AJSS 2014, 4, 63-74.

29. Autio, E.; Fu, K. Economic and political institutions and entry into formal and informal entrepreneurship. Asia Pac. J. Manag. 2015, 32, 67-94. [CrossRef]

30. Black, S.; Strahan, P. Entrepreneurship and bank credit availability. J. Financ. 2002, 57, 2807-2833. [CrossRef]

31. Hurst, E.; Lusardi, A. Liquidity constraints, household wealth, and entrepreneurship. J. Political Econ. 2004, 112, 319-347. [CrossRef]

32. Kim, P.H.; Aldrich, H.E.; Keister, L.A. Access (not) denied: The impact of financial, human, and cultural capital on entrepreneurial entry in the United States. Small Bus. Econ. 2006, 27, 5-22. [CrossRef]

33. Mueller, P. Entrepreneurship in the region: Breeding ground for nascent entrepreneurs? Small Bus. Econ. 2006, 27, 41-58. [CrossRef]

34. Aghion, P.; Fally, T.; Scarpetta, S. Credit constraints as a barrier to the entry and post-entry growth of firms. Econ. Policy 2007, 22, 731-779. [CrossRef]

35. Musso, P.; Schiavo, S. The impact of financial constraints on firm survival and growth. J. Evol. Econ. 2008, 18, 135-149. [CrossRef] 
36. Klapper, L.; Amit, R.; Guillén, M.F. Entrepreneurship and firm formation across countries. In International Differences in Entrepreneurship; Lerner, J., Schoar, A., Eds.; University of Chicago Press: Chicago, IL, USA, 2010; pp. 129-158.

37. Werner, A. Do credit constraints matter more for college dropout entrepreneurs? Int. J. Enterpren. Innovat. Manag. 2011, 14, 190-205. [CrossRef]

38. Paniagua, J.; Sapena, J. The effect of systemic banking crises on entrepreneurship. In New Challenges in Entrepreneurship and Finance; Peris-Ortiz, M., Sahut, J.M., Eds.; Springer: Cham, Switzerland, 2015; pp. 195-207.

39. Global Entrepreneurship Monitor. GEM Key Indicators. Available online: http:/ /www.gemconsortium.org/ data/key-indicators (accessed on 10 March 2017).

40. World Bank. Data Bank. Available online: http://databank.worldbank.org/data/home.aspx (accessed on 25 March 2017).

41. Hoffmann, A.; Larsen, M.; Oxholm, A.S. Quality Assessment of Entrepreneurship Indicators; National Agency for Enterprise and Construction's Division for Research and Analysis (FORA): Copenhagen, Denmark, 2006.

42. Vidal-Suñé, A.; Lopez-Panisello, M.B. Institutional and economic determinants of the perception of opportunities and entrepreneurial intention. Investig. Reg. 2013, 26, 75-96.

43. Briscoe, G.; Dainty, A.; Millett, S. The impact of the tax system on self-employment in the British construction industry. Int. J. Manpow. 2000, 21, 596-614. [CrossRef]

44. Bruce, D.; Mohsin, M. Tax policy and entrepreneurship: New time series evidence. Small Bus. Econ. 2006, 26, 409-425. [CrossRef]

45. Djankov, S.; Ganser, T.; McLiesh, C.; Ramalho, R.; Shleifer, A. The Effect of Corporate Taxes on Investment and Entrepreneurship. Am. Econ. J. Macroecon. 2010, 2, 31-64. [CrossRef]

46. Salman, D.M. Mediating role of research and development on entrepreneurial activities and growth: Evidence from cross-country data. WJEMSD 2014, 10, 300-313. [CrossRef]

47. Shapero, A. The role of entrepreneurship in economic development at the less-than-national level. In Expanding the Opportunity to Produce: Revitalising the American Economy through New Enterprise Development; Froedman, R., Schweke, W., Eds.; The Corporation for Enterprise Development: Washington, DC, USA, 1978; pp. 25-35.

48. Gibb, A.A.; Ritchie, J. Understanding the Process of Starting Small Businesses. Eur. Small Bus. J. 1982, 1, 26-46. [CrossRef]

49. Perotti, E.C.; Volpin, P.F. Lobbying on Entry. EFA 2004 Maastricht Meetings Paper 2277. Available online: https: / / papers.ssrn.com/sol3/papers.cfm?abstract_id=558588 (accessed on 10 April 2017).

50. Singh, G.; De Noble, A. Early Retirees as the Next Generation of Entrepreneurs. Entrep. Theory Pract. 2003, 23, 207-226. [CrossRef]

51. Meyer, K.E.; Sinani, E. When and where does foreign direct investment generate positive spillovers? A meta-analysis. J. Int. Bus. Stud. 2009, 40, 1075-1094. [CrossRef]

52. Görg, H.; Strobl, E. Multinational Companies and Indigenous Development: An Empirical Analysis. Eur. Econ. Rev. 2002, 46, 1305-1322. [CrossRef]

53. Doytch, N.; Epperson, N. FDI and Entrepreneurship in Developing Countries. GSTF Bus. Rev. 2012, 1, 120-125.

54. Kim, P.H.; Li, M. Injecting demand through spillovers: Foreign direct investment, domestic socio-political conditions, and host-country entrepreneurial activity. J. Bus. Ventur. 2014, 29, 210-231. [CrossRef]

55. Djankov, S.; Hoekman, B. Foreign Investment and Productivity Growth in Czech Enterprises. World Bank Econ. Rev. 2000, 14, 49-64. [CrossRef]

56. Konings, J. The Effects of Foreign Direct Investment on Domestic Firms: Evidence from Firm Panel Data in Emerging Economies. Econ. Transit. 2001, 9, 619-633. [CrossRef]

57. De Backer, K.; Sleuwaegen, L. Does foreign direct investment crowd out domestic entrepreneurship? Rev. Ind. Organ. 2003, 22, 67-84. [CrossRef]

58. Sabirianova, K.; Svejnar, J.; Terrell, K. Distance to the efficiency frontier and foreign direct investment spillovers. J. Eur. Econ. Assoc. 2005, 3, 576-586. [CrossRef]

59. Ayyagari, M.; Kosová, R. Does FDI facilitate domestic entry? Evidence from the Czech Republic. Rev. Int. Econ. 2010, 18, 14-29. [CrossRef] 
60. Van der Zwan, P.; Thurik, R.; Verheul, I.; Hessels, J. Factors influencing the entrepreneurial engagement of opportunity and necessity entrepreneurs. Eurasian Bus. Rev. 2016, 6, 273-295. [CrossRef]

61. Vivarelli, M. Is entrepreneurship necessarily good? Microeconomic evidence from developed and developing countries. Ind. Corp. Chang. 2013, 22, 1453-1495. [CrossRef]

62. Olivari, J. Entrepreneurial traits and firm innovation. Eurasian Bus. Rev. 2016, 6, 339-360. [CrossRef]

63. Singer, S.; Amorós, J.E.; Arreola, D.M. Global Entrepreneurship Monitor 2014 Global Report. Available online: http:/ / www.gemconsortium.org/report (accessed on 20 March 2017).

64. Klapper, L.; Love, I. The impact of the financial crisis on new firm registration. Econ. Lett. 2011, 113, 1-4. [CrossRef]

65. Van Steel, A.; Carree, M.; Thurik, R. The effect of entrepreneurial activity on national economic growth. Small Bus. Econ. 2005, 24, 311-321. [CrossRef]

66. Dejardin, M.; Fritsch, M. Entrepreneurial dynamics and regional growth. Small Bus. Econ. 2011, 36, $377-382$. [CrossRef]

67. Fritsch, M.; Mueller, P. The effect of new business formation on regional development over time: The case of Germany. Small Bus. Econ. 2008, 30, 15-29. [CrossRef]

68. Van Stel, A.; Suddle, K. The impact of new firm formation on regional development in the Netherlands. Small Bus. Econ. 2008, 30,31-47. [CrossRef]

69. Plehn-Dujovich, J.M. The Dynamic Relationship between Entrepreneurship, Unemployment and Growth: Evidence from U.S. Industries. Available online: https:/ / www.sba.gov/sites/default/files/rs394tot.pdf (accessed on 8 September 2017).

70. Kennedy, P. A Guide to Econometrics, 6th ed.; Wiley-Blackwell: Cambridge, UK, 2008; ISBN 978-1-4051-8257-7.

71. Anderson, D.R.; Sweeney, D.J.; Williams, T.A. Essentials of Statistics for Business and Economics, 4th ed.; South-Western College Publishing: Cincinnati, OH, USA, 1990.

72. Bryman, A.; Cramer, D. Quantitative Data Analysis with SPSS Release 10 for Windows: A Guide for Social Scientists; Revised Edition; Routledge: London, UK, 2001; ISBN 0-415-24400-5.

(C) 2017 by the authors. Licensee MDPI, Basel, Switzerland. This article is an open access article distributed under the terms and conditions of the Creative Commons Attribution (CC BY) license (http:/ / creativecommons.org/licenses/by/4.0/). 